Article

\title{
LEARNING FROM AND TRANSLATING PEASANT STRUGGLES AS ANTICOLONIAL PRAXIS: THE GHADAR PARTY IN PUNJAB
}

\author{
KASIM ALI TIRMIZEY \\ York University
}

\begin{abstract}
The Ghadar Party introduced a radical anticolonial praxis to Punjab, British India, in the early 1910s. Much of the literature on the Ghadar Party situates the birth of the movement among Punjabi peasants along the Pacific coast of North America who returned to their homeland intent on waging an anticolonial mutiny. One strand of argumentation locates the failure of the Ghadar Party in a problem of incompatibility between their migrant political consciousness and the conditions and experiences of their co-patriots in Punjab. I use Antonio Gramsci's concept of "translation," a semimetaphorical means to describe political practices that transform existing political struggles, to demonstrate how the Ghadar Party's work of political education was not unidirectional, but rather consisted of learning from peasant experiences and histories of struggle, as well as transforming extant forms of peasant resistance - such as, banditry - for building a radical anticolonial movement. Translation is an anticolonial practice that works on subaltern experiences and struggles. The Ghadar Party's praxis of translating subaltern struggles into anticolonialism is demonstrative of how movements learn from and transform existing movements.
\end{abstract}

\section{Keywords}

The Ghadar Party; Punjab; anticolonialism; peasantry; translation; hegemony; Gramsci; Fanon; social movement learning.

When Britain entered the war in the summer of 1914, Kartar Singh, an eighteen year old militant with the Ghadar Party branch in San Francisco, along with other members, immediately made preparations to return to Punjab to raise a rebellion. One estimate was that about 8,000 ghadaris from across North America, East Asia, and other locations returned to Punjab over the next two years to wage an anticolonial insurrection (Ramnath 2011). When they arrived in Punjab they were divided into jathas or small bands, with many organizing series of dacoities (armed robberies) as a means of financing their anticolonial rebellion. Kartar Singh, who led one jatha, reprimanded Dilip Singh for suggesting to rob a relative just because he had disagreements with him. Kartar emphasized that their mission was not to engage in personal revenge, but rather was to overthrow British colonialism. Kehar Singh, another returned emigrant, suggested robbing a 
rich man's house in his village, Sahnewal, in Ludhiana district. Once there, the band had someone watching the police station while others went inside the house of their target. They didn't find much loot in the house. When one dacoit was about to sexually abuse a female inhabitant, Kartar's second-in-command threatened to shoot the dacoit if he continued. The next target for a dacoit was a few days later at Mansurian village in the same district. There they targeted a Hindu moneylender. Kartar and Dilip remained on guard outside, while the other dacoits took the loot inside. While some villagers started gathering out of curiosity outside the house, Kartar explained to the villagers that they shouldn't worry as they were collecting money to attack the British. When the dacoits opened one of the safes, the deeds and debt logs were burned, a common practice among peasants to protest against exploitative debt relations. Boxes of gold and silver ornaments and coins were taken. When a retired high ranking officer of the British India Army from the neigbouring village arrived, he led an attack by firing on the dacoits. The ghadari militants responded by throwing inkbombs, leaving a cloud of smoke and a path for their getaway (Isemonger and Slattery 1919, 98-100). Kartar would also have an important role in convincing troops in the Ferozepur cantonment to join the Ghadar Party in a mutiny. However, the British foiled the Ghadar Party plans at an anticolonial rebellion through massive repression enabled by the Defence of India Act of 1915. This included the arrest of Kartar Singh and other ghadari colleagues. Karta was sentenced to death, was hanged in Central Jail of Lahore on November of 1915 (Puri 1993), and is remembered for going to the gallows with his head held high.

While Kartar Singh's and his colleagues' exploits in banditry may seem like a rather insignificant aspect in the history of the Ghadar Party - after all, dacoity is an under-examined aspect of their activities in academic and popular literature - it uncovers integral aspects of their political praxis. Namely, it shows the messy character of anticolonialism: militants did not all agree on the priorities of rebellion, and personal vendettas and interests mixed with the grander goal of ending the British empire. Anticolonialism was something that was learnt, and its specific character emerged through practice, dialogue, and contestation. The above narrative also points to how anticolonialism emerged through the process of transforming or translating peasant struggles, in this case by building upon contests with moneylenders.

\section{The Ghadar Party}

The Ghadar Party is situated within the second phase of anticolonialism in the Indian subcontinent. The first wave of anticolonial organizing began with the mutiny of 1857 . The second included mobilizations against the partition of Bengal and in Punjab protests in 1907 over water rates and paternalistic colonial state regulations. While the latter protests had some articulations of anticolonialism, it was with the formation of the Ghadar Party in 1913 that Punjab was introduced to a more systematic and radical anticolonial praxis. The literature on the Ghadar Party situates the birth of the movement among Punjabi peasants and Indian intellectuals along the Pacific coast of North America (Puri 1993; Bains 1962; Ramnath 2011; Josh 1977). What follows 
in that narrative is how after politicization in North America, Punjabi peasants returned to their homeland intent on waging an anticolonial mutiny among the peasantry, landless labourers, and native soldiers. Harish Puri (1993) locates the failure of the Ghadar Party in the impossibility of interpreting their migrant political consciousness to provide meaning to the social conditions of their co-patriots in Punjab. Further, he argues that their lack of organization skills led to their demise. This paper argues that the Ghadar Party did not encounter limits in bridging their anticolonial politics from North America to Punjab. Rather, they were quite successful in "translating" extant forms of socio-political struggles into radical anticolonialism. I also examine whether the appearance of a lack of coherent organizing was a belief in spontaneity and an undermediated notion of rebellion. What is often ignored in the literature on the Ghadar Party is how they developed upon extant forms of peasant resistance, as well as the sentiments of alienation and desires of the subaltern classes. In this essay, I examine how the Ghadar Party learned from peasant banditry for building an anticolonial popular collective will.

Migration from Punjab to United States and Canada began at the turn of the twentieth century due to an agrarian crisis. Most migrants were peasants from the eastern districts of Jullundur and Hoshiarpur and some were from the canal colonies in western Punjab. The majority of the migrants were Sikh, followed by Muslims and Hindus. Half were ex-soldiers who had served in the British Indian Army (Puri 1993). Most of these Punjabi migrants settled close to the Pacific coast. Those around Vancouver Island and Victoria worked in railway construction, saw mills, and fruit farms. Some settled as far as Calgary and Edmonton working in coal mines. In the USA, migrants worked as labourers or tenant farmers in the Sacramento Valley, California, others in lumber mills in Oregon and Washington state (Puri 1993). There were also Indian students in universities in California.

The Punjabi labourers and Indian students that would form the Ghadar Party in 1913 developed their political consciousness through their shared experiences of white supremacy and class exploitation in North America. The Ghadar Party developed a radical critique of colonialism and imperialism which went further than that of Indian liberal nationalists. They experienced class and racialization in the workplace through differentiated wages with threats of deportation, special immigration regulations for Asians, and anti-Asian riots. This context was an opportunity to understand class exploitation and racialization as being structured by imperialism. They also saw their oppression in North America as being connected to British colonialism in India. Rather than making claims for extending liberal rights to the South Asian community in the United States and Canada, they made calls for ending empire.

They had published a newspaper out of their San Francisco office called Ghadar and a regular collection of poetry titled Ghadar-di-Ghanj (Echoes of Mutiny). Their network expanded to include branches in Vancouver, Portland, Panama, Berlin, Mexico City, Moscow, London, Paris, Buenos Aires, Cape Town, Lahore, Singapore, and Tokyo. With the beginning of the Great War, they called upon their members to return to Punjab to start a mutiny among the soldiers of the 
British Indian Army. This call for an anticolonial insurrection among Indian sepoy "echoed" another anticolonial moment - that of the 1857 mutiny (Elam 2014). The Ghadar Party had a major set-back when the planned uprising in the winter of 1914-1915 was repressed and many ghadaris sent to jail or killed by the colonial state in Punjab.

Several scholars have attributed the failure of the Ghadar Party to develop a successful mass struggle against the British Empire on questions of ideology and organization. Harish Puri ${ }^{2}$ (1993) has argued that the ghadaris who returned to Punjab in 1914 and 1915 failed to develop a mass movement among peasants, soldiers, and labourers because there was a separation between the consciousness of the returned migrants and the native population, which the former were unable to bridge through the dissemination of political ideology. Similar assessments are made in colonial intelligence reports that argue that the Punjabis in North America had become disconnected with the realities in Punjab (Isemonger and Slattery 1919). There were real differences in the experiences between the recently returned Punjabis and their co-patriots in Punjab, however, this was a separation that could be overcome. The assumption in Puri's analysis is that ideas cannot be translated across space and experience. The Ghadar Party's analysis of empire was precisely an acknowledgement of the ways in which political unity could be produced through anti-imperialism because of the translatability of particular experiences of exploitation and oppression across empire.

Another commonly attributed reason for the failure of the Ghadar Party was to questions of organization: that the leadership lacked political organizing skills (Puri 1993, 148) and had "poor coordination" (Sarkar 1990, 147). There existed two sets of groups within the party: a small group of Indian university students (mostly Hindu Bengalis) and a large number of Punjabi labourers. The students assisted the core leadership at the headquarters in San Francisco on developing their propaganda and the party organ, Ghadar. The Punjabi labourers were spread across the Pacific coast and did the grunt work of developing branches, spreading propaganda, and collecting funds. The collaboration between the Bengali students and Punjabi labourers created an uneasy alliance, with internal disputes and divisions arising from class and ethnic prejudices as well as political differences. The Bengali students' idea of anticolonial revolution consisted of secret organization, military training, terrorism, and collaborating with Bengali revolutionary movements (Puri 1993). In contrast, the Punjabi labourers were more concerned with developing a mass movement through political education (Puri 1993, 154). With the arrival of World War I in the summer of 1914, most of the Bengali students were interested in organizing through the Berlin-based Indian Independence Committee, thus leaving most of the Ghadar organizing to the Punjabi labourers. The various branches across USA, Canada, East Asia, Latin America, and Africa had an autonomous relationship with respect to the headquarters in San Francisco. A branch could consist

\footnotetext{
1 A sepoy was the title used for a native soldier in the British Indian Army.

2 Whereas my engagement with the literature on the Ghadar Party focuses on a critique of Harish Puri's text, this is only because his laudable text is an often cited work on the party as well as its focus overlaps with the central concerns of my essay, that is questions of organization, spontaneity, and ideology.
} 
of a small group or band, sometimes Punjabi labourers at a common workplace like a specific mill and farm. In some cases branches were initiated through the political education of party workers who travelled across the North American Pacific coast. In other cases, Punjabi labourers in the diaspora who had come across the newspaper Ghadar, were persuaded by its cause, formed a branch that operated autonomously from the headquarters, while being inspired by the directives that came through the party organ (Puri 1993). Puri criticizes the Ghadar Party leadership for not developing a coherent and centralized organizational structure. Puri describes the Ghadar Party as a "spontaneous and pre-organized movement," a quality that he associates due to the majority of the membership being peasants and this being typical of peasant rebellions (Puri 1993, 168). I agree that there was a non-hierarchical party organization, a lack of coordination, and an emphasis on spontaneous activity. Yet, this wasn't because of a lack of organizational skills nor a tendency among the peasantry towards spontaneity.

The theoretical and conceptual framework of Antonio Gramsci is very appropriate for an analysis of the Ghadar Party. While Gramsci, the Italian communist militant and intellectual, has been considered by Perry Anderson to belong to the universe of "Western Marxism" and could be considered as being irrelevant to non-Western contexts, the specific dynamics within Italian history provides a useful comparison that makes Gramsci's analysis worthy of translating for studying colonial and post-colonial societies (Kiernan 1995; Hall 1996). During the nineteenth and early twentieth century, Italy was at the (semi-)periphery of capitalism. ${ }^{3}$ Italy had a majority peasant population embedded in an agricultural economy with comparatively lower productive capacity. Southern Italy existed in a semi-colonial relationship with northern Italy. This was a reflection of southern agriculture in a dependant relationship with northern industry and racial ideologies of southern inferiority were in operation (Green 2013). The deployment of Gramsci for the purpose of studying colonial India was previously advanced by the subaltern studies collective (Chatterjee 1986; Guha 1997). The subaltern studies collective brought an important contribution in critiquing colonial and liberal nationalist historiography by emphasizing the actions of subaltern classes. However, the subaltern studies collective would come to cast Gramsci conceptual universe in terms of discursive aspects of ideology, and under-emphasize the historicity of material relations. I develop upon the recent philological turn in Gramscian studies that places importance on Gramsci's “absolute historicism” (Thomas 2009; see also Santucci 2010; Ives 2004a; Ives 2004b).

Gramsci is relevant to this study especially in how his inquiry into the unification of Italy provides insights for analyzing how various social and political forces attempted to produce a national-popular collective will. This essay would not be the first attempt at translating Gramsci for the study of the Ghadar Party; Harish Puri (1993) brought Gramscian concepts to work in his own analysis of the party. While Puri makes use of Gramsci to examine the role of spontaneity and organization, and traditional and organic intellectuals, these are usually treated as dichotomies,

\footnotetext{
${ }^{3}$ Italy held a peripheral and weak position within Europe. It was the site of foreign occupation by Austria-Hungary and required military assistance from France for its liberation. However, the peripheral nature of Italy should not be overstated either: Italy was nonetheless a colonial power, with a presence in Libya, Tunisia, and Eritrea.
} 
whereas Gramsci saw them in a dialectical and dynamic relationship to one another. The next section examines Gramsci's concepts of translation, the popular collective will, spontaneity, and organization.

\section{Gramsci on Translation}

Gramsci's concept of "translation"4 provides a framework for uncovering the transformation of socio-political struggles in a hegemonic moment. Gramsci used the Italian word tradurre, which means linguistic "translation," but also "to express," "to interpret," "to transfer," "to summon." Tradurre's etymological root is the Latin tradere, which means to "hand over," and is shared with "traitor" and "tradition" (Ives 2004a). This etymology unveils how translation entails a dialectical relationship between change and continuity, revolution and restoration, that is to say how meaning is transformed while maintaining elements from an earlier moment (Ives 2004a, 101).

Gramsci believed in the possibility of translation across time and space, but this was never a simple process of transposition from the source to the target language. Gramsci used the concept tradurre for teasing out what could be learned from the experience of the Russian Revolution in Italy. He recognized that a process of selective betrayal and faithfulness was required in transferring the experience of the Russian Revolution into the geography of Italy, especially given differences in state-society relations and the organization of rule. Gramsci wrote about how in Tsarist Russia "the state was everything," such that a strategy of a "war of maneuvre" made sense (Gramsci 1971, 238). Whereas in Western Europe and in Italy, Gramsci saw a greater role for the "war of position" given how there was a more developed relationship between state and civil society.

Translating revolution across time-space was open to producing something of a passive character, that is to say being a transformation from above rather than below. This was Gramsci's conclusion in examining how the French Revolution was taken up by the movement for Italian unification (Risorgimiento) in the mid-nineteenth century. Gramsci discussed how one Giuseppe Ferrari "was incapable of 'translating' what was French into something Italian, and hence his very "acuteness" became an element of confusion, stimulated new sects and little schools, but did not impinge on the real movement" (Gramsci 1971, 65). The passive quality of the Italian Risorgimiento was the consequence of mis-translating ideas developed in an international order characterized by uneven development (Morton 2007, 68-69). Ideas of the modernization of rule born in an advanced capitalist country became disfigured when mechanically translated to the peripheries of capital. For Gramsci, the idea of passive revolution denoted a condition where modernization of rule occurred without an organic basis, that is they came from an external influence or imposed from above at a moment when the necessary objective and subjective conditions were not fertile.

4 Translation here is used in the double sense of literary translation and a metaphor of socio-political practice. 
Translation for Gramsci entailed a process of transformation or revolution of the target language. Party organic intellectuals are involved in the process of "active translation", transforming language, producing a new language from the existing one, and producing a new political subject from the material of social life (Ives 2004a). Said differently, translation as a political project is not just a process about introducing from outside ideas and forms of social relations, but was a process of organizing and bringing coherency to the spontaneous activities of subaltern classes.

Spontaneous action arises out of the lives of subaltern classes and their understanding of exploitation and domination. In a reference to a revolt by small farmers, Gramsci described how a flour tax severely affected their capacity for subsistence and led them to kill and beat tax collectors. He described these actions as spontaneous, that is the movement was without organization and conscious leadership (Gramsci 1992, 1:Q1\$43). Elsewhere, Gramsci discusses spontaneity in a more complex relationship with conscious leadership. Gramsci states that pure spontaneity does not exist. In so-called spontaneous movements "there exist multiple elements of 'conscious leadership' but no one of them is predominant or transcends the levels of a given social stratum's 'popular science' - its common sense" (Gramsci 1971, 196). In discussing the Turin workers movement, Gramsci says that "elements of 'spontaneity' were not neglected and even less despised" (Gramsci 1971, 198). Gramsci continues by explaining the elements of spontaneity: "it [the workers struggle] applied itself to real men, formed in specific historical relations, with specific feelings, outlooks, fragmentary conceptions of the world." Spontaneity combined with conscious leadership provides an organic relationship with the everyday reality of dominated classes: "This unity between 'spontaneity' and 'conscious leadership' or 'discipline' is precisely the real political action of the subaltern classes, in so far as this is mass politics and not merely an adventure by groups claiming to represent the masses" (Gramsci 1971, 198).

The appeal to spontaneity made by Gramsci is expressed well by Fanon who saw there existing "a time-lag, or a difference of rhythm" (Fanon 2001, 85) between leaders of liberal nationalist movements and subaltern classes. In addition, we can find within spontaneity a form of political action that expressed the experience of alienation and the desires of subaltern groups. Fanon gives the example of how the question of subsistence can take central importance to subaltern classes but is ignored by liberal nationalists:

The people, on the other hand [in contrast to the native liberal intellectual], take their stand from the start on the broad and inclusive positions of bread and the land: how can we obtain the land, and bread to eat? And this obstinate point of view of the masses, which may seem shrunken and limited, is in the end the most worthwhile and the most efficient mode of procedure (Fanon 2001, 50).

Fanon outlines how the "geography of hunger" (Fanon 2001, 96) is another marker of the "Manichean world" (Fanon 2001, 41) of colonialism and imperialism. Spaces are defined between the colonizer and colonized, between the stuffed and starved. However, as James Scott points out 
hunger and exploitation do not necessarily translate into outright rebellion. And when working communities do resist, it may consist of "everyday forms of resistance," such as theft, banditry, or murder. In moments of subsistence insecurity, the target of resistance is a strategic calculation and in relation to subaltern consciousness of the geography of hunger - whether the perception of the source of hunger is due to the merchant, the state, or empire. Yet, there is always the possibility of re-configuring the target and content of political struggles. Scott's work provides evidence of everyday forms of peasant resistance in colonial Burma and Vietnam being translated into anticolonialism under different types of organizing - peasant, communist, and millenarian (Scott 1976).

A central inquiry for Gramsci, as well as Fanon, was how to develop a national-popular collective will among a fragmented and dominated population. The development of this unity required "translating" the common sense and the spontaneous movements of the subaltern classes to develop a collective will (Lo Piparo 2010). Gramsci envisioned a national-popular being developed as a hegemonic project through a process of unification. Yet, this was not meant to dissolve heterogeneity that is entailed in the fragmented and spontaneous feelings, thoughts, actions, and desires of the subaltern groups. Rather, the party worked to uncover difference due to exploitation and oppression and bring coherence to the social formation through mutual transformation.

The Ghadar Party attempted to develop a popular collective will by translating the fragmented feelings of alienation, desires, and struggles among the subaltern classes. I examine here how the Ghadar Party translated peasant struggles against money-lenders for developing an anticolonial popular collective will.

\section{The Echo of Banditry}

Ghadar was both party name and action. A British dictionary of Urdu from late nineteenth century defined it as: "perfidy, faithlessness, ingratitude; fraud, villainy; mutiny, rebellion, sedition, riot, disturbance, confusion, tumult, noise, bustle" (Platts 1884, 769). These connotations of ghadar as a negative and irrational form of political action was a reflection of imperial views of anticolonial resistance. The Ghadar Party's use of the term ghadar reflected a range of political actions including sepoy mutiny, riot, rebellion, and banditry, and acknowledged its translatability across time and space.

The Ghadar Party referenced the way in which their call for ghadar "echoed" the anticolonial mutiny of 1857 in the title of a poetry collection: Ghadar-di-Gunj or "Echo of Mutiny." Gunj can be translated from Urdu as "echo," "resonance," or "roar." Its origin is in the Sanskrit root word gunjan, meaning "vibration" or figuratively "an intense and continuous resonance." Echoing of mutiny was a means of establishing their organizing within a lineage of popular anticolonial rebellions that was highlighted by 1857 . The Ghadar Party placed the tactic of ghadar at the center of their political organizing. That is, they saw the necessity of armed struggle and 
developing a front among the native sepoy and peasantry. Just as with an audible echo, the Ghadar Party's invocation of ghadar consisted in a shift in time and space from the roar of 1857 . The term gunj finds resonance with Gramsci's "translation," in the sense both terms evoke the importance of learning from past struggles yet transforming modes of resistance to adapt to new contexts. Ghadar-di-gunj can also reference the ways in which the Ghadar Party developed upon the practice of peasant banditry to transform it into an anticolonial practice.

When Great Britain declared war on Germany on August 4th, 1914, the Ghadar Party took this as an opportunity to transform their general call for anticolonial mutiny to making concrete this political action. Prior to this moment, Germans were regarded as sympathizers of national liberation of India, as they had a common enemy - England. Now, on the date that Great Britain entered into war, the Ghadar Party issued their own declaration of war through their party organ in an article titled The Bugle of War, where Indians were called to support Germany in the war effort (Isemonger and Slattery 1919, 17). The Ghadar Party mobilized their branches along the Pacific Coast through their party organ and in meetings to get masses of Punjabi labourers to return to their native Punjab to ignite an insurrection. The first goal upon their return was to raise funds through dacoity and to bring peasants, labourers, and sepoy into their fold.

The Ghadar Party's use of dacoity was more than just a convenient means for raising funds. Dacoity was one of the ways for peasants, landlords, and agrarian labourers to struggle against the influence of rural money-lenders, dominated by the Hindu bania ${ }^{5}$ caste. The Ghadar Party developed on this mode of resistance to give it an anticolonial and anti-imperialist character. The potential relationship between banditry and anticolonialism can be teased out from the moment of February and March 1915, which witnessed both an attempted anticolonial mutiny by the Ghadar Party in central Punjab, and grain riots and banditry in southwestern Punjab.

In February of 1915, food prices and tensions were rising across the whole of the Punjab. These antagonisms developed into grain riots and dacoity in the southwest of the province from February to March of that year. Muslim zamindars (large landowners), tenant farmers, and landless labouring castes responded to the extreme high price of food by rioting against Hindu bania, who had taken advantage of the relative scarcity (Sohan et al. 1915; O'Dwyer 1925; Gandre 1986). This was the product of a war economy that prioritized the export of grain for feeding troops on the western front. On the one hand, Muslim zamindars from so-called martial castes benefited from military postings and land grants. But on the other hand, the war economy showed how bania controlled the subsistence of agrarian classes. Rioting by agrarian Muslims was a tactic to take relative control over subsistence and land against Hindu bania.

In the midst of those events, on the 19th of February, police raided a home in Gawal Mandi, Lahore, suspected by the government of being occupied by "Sikh revolutionaries." One pamphlet that was found at the house read:

\footnotetext{
5 As a way of shorthand I refer to the Hindu money-lending castes as bania, which was the dominant money-lending caste in Punjab. Yet, there were a range of castes that worked in this profession depending on the region. For example, in southwestern Punjab, the aroras were the dominant Hindu money-lending caste.
} 


\section{Dear Indians:}

Just think a little, you and your country's state, what is happening to them. This country, which of all countries was considered the greatest, today is being destroyed under the feet of foreigners. Which country is the most fruitful in the world? This country's children today are dying of starvation. What is the reason for this? Why are you in this state? Does your grain in your country become less? Certainly not. Much more grain is being produced now than used to be produced, but this is all going to foreign lands. The grain produced in your country you are not allowed to eat (quoted in Punjab Government 1915, 193).

The pamphlet was the work of the Ghadar Party. It is unknown if this pamphlet, which was originally written months prior to the food price hike, was strategically reprinted given the contemporary circumstances. Yet, we know the Ghadar Party was unconnected to the grain riots in the southwest of the province because this region was not a zone of Ghadar organizing and the grain riots did not espouse explicit anticolonial politics. ${ }^{6}$

Nonetheless, there are at least two ways in which the grain riots of 1915 and the Ghadar Party are similar. First, they were both distinct responses to colonialism and imperialism. The grain riots were a critique of the restriction of food entitlement, which that was the outcome of imperialism and colonialism. As seen in the pamphlet above, the Ghadar Party made those connections between the imperial question and the right to subsistence. To this effect, the Ghadar Party worked to conspire against the colonial state and allied forces. In contrast, the grain riots of southwestern Punjab targeted Hindu bania. The targeting of bania rather than the colonial state might have been because it was a strategic choice for immediately and partially resolving the contradictions of colonial society. Second, ghadaris drew upon the repertoire of peasant forms of resistance, such as dacoity, that were used in the grain riots of 1915.

Social banditry was an extant form of class action by agrarian social forces in Punjab. Dacoity was a frequent strategy used by agrarian landlords, landless labourers, and peasants in their struggle against bania for control over agricultural surplus production. Bania were not just moneylenders for agrarian classes, but often dealt in commercial activity, particularly as merchants of agricultural production. Neeladri Bhattacharya explains that "the object of the merchantmoneylender was not to earn interest as such, but to control prices of purchase and sale, and ensure regular channels for the supply and disposal of commodities. Since rural traders could not always determine the price at which they sold their stocks to wholesalers in mandis, they attempted to exercise their control at the points of supply in the village" (Bhattacharya 1985, 307). After harvest,

\footnotetext{
6 Preparations were made by Ghadar militants to visit Rajput soldiers in the Multan Cantonment, located in the southwestern Punjab during the winter of 1914-1915 (Isemonger and Slattery 1919). But it is unconfirmed if this plan was ever carried out.
} 
the bania came around to take the produce against the zamindar's debt. The control that banias held over agricultural production was such that increases in food prices benefited them, not producers. At times of high food prices dacoity and petty theft increased, and frequently was directed against the bania.

During years of famine there was a considerable increase in crime - dacoity, robbery, criminal trespass, house-breaking, and theft - as a strategy for subsistence. Famines brought greater distrust upon the bania. In the famines of 1868-70, grain-merchants stored grain, mixed wheat with lower-grade grains, and raised food prices (Punjab Central famine relief committee $1870,9)$. The export of grain continued despite a food shortage. In the Hissar district, it was reported that exports in grain exceeded imports, with three-fourths of the population requiring food relief (Punjab Central famine relief committee 1870, 27). During the famines of 1877, grain riots occurred in eastern Punjab, mainly in Delhi, Amballah, Gurgaon, Karnal, and Rohtak districts (Commission 1878, I-2/35). Traders in Delhi speculated on grain prices, which drove prices up but also resulted in grain riots. Instances of dacoity increased during the famine. In many cases zamindars sold grain to the bania out of obligation. Zamindars, being hard pressed for food, formed dacoits to prevent the export of grain from villages to Delhi (Commission 1878, 5). Grain riots occurred in Rohtak district where dacoits broke into and looted 37 grain shops (Commission 1878, ix). The colonial administration frequently organized food-for-work programs during famines as a means of getting labour for public works. Authorities claimed that engaging the starving masses in such labour programs could prevent them from resorting to crime for survival (Commission 1878, I-2/19). Mike Davis termed famines as "redistributive class struggles" (Davis 2001, 20). Famines don't just create victims, they make it easier to transfer property between classes. Whereas greater privileges were accumulated by the bania in times of hunger, peasants and landlords made efforts to sabotage bania holdings through theft, looting, banditry, and rioting.

The Ghadar Party translated dacoity into a broader political practise by giving it articulations of anti-imperialism. This was accomplished by linking questions of food insecurity to the British Empire's presence in India. Since the 1870s, cash crops like wheat and cotton were growing with increasing intensity in Punjab for export. Punjab was opened up for providing cheap food for the heart of the empire through the construction of irrigation networks, canal colonies, roads, market towns, railway system, and an export port in Karachi. The industrial revolution in Western Europe was on the backs of agricultural labourers in the colonies providing factory workers in Western Europe with cheap food (Patnaik 2011). The vagaries of the emerging international grain market would be a determining factor in the local price of wheat. The higher demands for a secure food supply to feed troops and citizens in England during World War I placed a greater burden on working communities in the colonies and was driving an increase in prices. The Ghadar Party articulated these dynamics in their literature in terms of the British Raj being a "drain" on India that lead to deprivation and hunger among the population. In various speeches, Ghadar activist Lala Har Dayal would expound on how the British Empire's drain on India's surplus production was leading to famine and destitution. He called the British Empire 
instead the "British Vampire" (quoted in Isemonger and Slattery 1919, 14). The analysis of the Ghadar Party on the question of food developed from the theories of Indian liberal nationalist Dadabhai Naoroji, specifically his "drain theory" (Naoroji 1901). Whereas Naoriji advanced the "drain theory" to support liberal nationalist politics of reforming colonial rule, the Ghadar Party found in this theory reasons for calling for the end of empire. Dacoity as re-constituted would be used for addressing both the immediate and root aspects of food insecurity.

The Ghadar Party made frequent calls for dacoity in their publications: "Commit dacoities in some places" (quoted in Waraich and Singh 2008, 292), "We should commit dacoity on the Government and awake the whole of the Punjab" (quoted in Waraich and Singh 2008, 292), "Plunder the treasuries" (quoted in Waraich and Singh 2008, 298), "Loot the plunders" (quoted in Tatla 2013,8). Dacoity was seen as a way to raise funds for their revolutionary organizing, which included acquiring resources for manufacturing bombs and arms. The ghadaris distinguished their activities from "social dacoity" or survival-oriented forms of dacoity. The Ghadar Party translated "social dacoity" into "political dacoity" for the purpose of revolutionary praxis. Elsewhere, the Ghadaris criticized the colonizers for calling them dacoits, instead of revolutionaries; the real dacoits were the British (Ghadar Party 1919).

Ghadari militancy appeared to the colonial state as unorganized and spontaneous in character, rather than being decentralized and organizing spontaneous initiative. With the homecoming of ghadiris in the fall of 1914, party members were divided into bands of sixteen with a leader in charge but decisions being made collectively. Nawab Khan, a ghadari militant, explained: "Each of us was to be in charge of a detachment of the emigrants whom we were to keep concealed in different places, ready, when the occasion arose, to unite together and carry out our campaigns. The reason for our thus distributing our force was to ensure safety for the remainder in case [the] Government succeeded in capturing one leader and his party" (quoted in Isemonger and Slattery 1919,67). Government intelligence reports commented that there existed next to little organization: "The various gangs wandered about from village to village to meet other returned emigrants, organise gatherings and look for likely places in which to commit dacoities" (Isemonger and Slattery 1919, 68). Further, they write that "they had broken up into small parties and wandered at random among the villages near their homes, preaching sedition when they found any one to listen and looking for favourable places for dacoities" (Isemonger and Slattery 1919, 70).

The principal target for dacoity mentioned in Ghadar texts is the colonial state. Specifically, targets listed included cantonments, police armouries, and district treasuries where agrarian tax revenue was deposited. Whereas plans and attempts were made at looting magazines at cantonments and a district treasury, when these were met with failure the focus shifted on raiding homes and shops of bania (Waraich and Singh 2008, 298-299; Isemonger and Slattery 1919). Returning to the common target of peasant banditry was described by the Ghadar Party as "political dacoity." This shift away from looting the colonial state reflected the practical difficulties of confronting its violent apparatuses. However, it was also a means for the party to include attacks on those native social forces that profited from imperialism at their expense - namely, the rural 
moneylender. Balwant Singh's gang made an attack on 21st of January at Sheikhupur village in Kapurthala State, looting six Hindu shops. On January 24th, the same gang robbed Hindu shopkeepers at the village of Alawalpur in Jullundur District (Isemonger and Slattery 1919). The gang led by Icchar Singh, a religious leader at a gudwara who held anti-British sentiment after the Rikabganj Gurdwara agitations, ${ }^{7}$ organized meetings at his gudwara. They organized a dacoity in Jhaner in the Maler Kotla State, where they attacked the home of money-lenders. The dacoits told the villagers not to be alarmed since they needed the money to fight the colonial state. A dacoity was organized on a moneylender in Chabba, a village near Amritsar, on January 4th of 1915. The ghadari militant who suggested the target actually owned money to this money-lender, and had suggested killing the old man, but the leader of the gang said they were not in the business of killing but only wanted money. The safe of the moneylender was opened by a locksmith working with the ghadaris. The gold and silver was taken and the debt bonds were burned.

The Ghadar Party's translation of dacoity into anticolonialism was not simply a process of transforming banditry into an anticolonial practise. Rather, in the process of political organizing, the meaning of anticolonialism took new form and content. Ghadari militants engagement with peasants expanded the targets of anticolonial praxis to include native social forces that supported and benefited from imperialism and colonialism. This contrasts the claims made by colonial officials that the Ghadar Party was out of touch with the peasantry. The colonial administration claimed that villagers, rather than being swayed by the revolutionaries, made attempts to stop the dacoits. They recount cases where unarmed villagers either captured or scared away the dacoits, this is despite the latter having guns, bombs, and swords (Isemonger and Slattery 1919, 108). British intelligence made claims that the acts of banditry actually alienated the peasantry as several cases show how they attacked the bandits. One British intelligence officer wrote: "These dacoities, on the Bengal model, had been recommended by the Ghadar for the collection of funds; but the authors of the scheme failed to consider the mentality of the Punjab peasant. The outrages committed, far from terrorising, only made him [the peasant] more keen to stamp out the perpetrators of them" (Isemonger and Slattery 1919, 103). It is true that accounts show that peasants and village officials like the zaildar (revenue agent over several villages) made efforts to attack the dacoits. However, what is left unmentioned in the colonists' analysis is that peasants and landless labour were never the bandits' target. Ghadar militants and peasants developed in dialogue the necessity of zeroing in on the common enemy of the peasant: the village money-lender. Peasant attacks on bania, however, took on the grammar of anticolonialism. The Ghadar Party's political organizing resulted in a transformation in the language of peasant resistance. In addition, peasant struggles transformed the language of the Ghadar Party.

7 The Rikabganj Gurdwara agitations began in 1913 among the Sikh community against the British Raj's demolition of a wall in a Sikh shrine in Delhi. 


\section{Organized Spontaneity}

Bands belonging to the Ghadar Party approached - and as the British would say, "contaminated" - sepoy and cavalry of the British Indian Army at cantonments across the Punjab and beyond in Meerut, Canwpore, Allahabad, Benares, Fyzabad, Lucknow, in the United Provinces, as well as those stationed in East Asia at Singapore, Burma, and Hong Kong with the message of ghadar. February $21^{\text {st }}, 1915$, was set by the party leadership as the beginning date for a mutiny to take place. Rather than a coordinated mutiny across the British Empire, it was hoped that initiating mutinies at the cantonment in Mian Mir (Lahore) and Ferozpore would generalize ghadar across the empire. 1857 was taken as a model for how rebellion could become "viral." In the end, an informant conspired against these plans and the uprising was interrupted before it could take off. A large number of ghadaris were arrested and put to trial through the Defence of India Act of 1915 in what would become known as the First Lahore Conspiracy Case. ${ }^{8}$

Members of the Ghadar Party believed that once an audacious act like the raiding of the magazine of a cantonment and attacks on European regiments had begun in one district, rebellion would spread. Ghadar Party publications warned people to be attentive to the beginning of a rebellion and then join in, "Look out for the time when the rising will take place and you will slay the enemy" (Ghadar quoted in Ker 1917, 125). The belief in spontaneity can also be noticed in an anonymous pamphlet attributed to Har Dayal by colonial intelligence, published on the 23rd December 1913, the one-year anniversary of the "Delhi Bomb," the bomb is considered as a harbinger or "political sermon" for revolution. ${ }^{9}$ The bomb is described as bringing political consciousness, particularly to the native soldiers:

The roar of the bomb represents the voice of the united nations. Who does not understand this? The Madrassi and the Bengal, the Punjabi and the Pathan, the educated and the uneducated - all understand the meaning of the bomb. How are we to convey the message of freedom to the Sikhs, the Gurkhas, and the Pathan in the Indian Army? These people are, in the first place, uneducated, and, secondly, they are confined in cantonments where it is difficult to approach them. [...] The [Delhi] bomb demonstrated to the Sikhs, Pathans, Gurkhas, Rajas, and Maharajas [sepoy standing on guard during the Viceroy's procession] in three seconds that the British kingdom in India was about to come to an end. The bomb in question was a national warning, by beat of drum, to the brave men of India to gird up their loins and come into the field of battle. [...] The existence of the bomb proves that oppression prevails in the country. In short, the use of the bomb and the pistol is

\footnotetext{
8 For detailed description on the averted insurrection, see (Puri 1993; Ramnath 2011).

9 The Delhi Bomb of 1912 was an unsuccessful attempt on the life of the Viceroy of India, Lord Hardinge. It was organized by underground anticolonial revolutionaries in Bengal and Punjab, and with the leadership of the Bengali anticolonial radical, Rash Behari Bose. Bose led the Punjab operations of the Ghadar Party in January of 1915.
} 
[sic.] the most effective weapon of the political sermon. [...] The bomb is the messenger of mutiny, and the fear of mutiny is the weapon for correcting the Government, while a general mutiny will be the means of its annihilation (Quoted in Ker 1917, 130-131).

This perspective was influenced by the anarchist strategy of "propaganda of the deed," that antistate actions like theft, rioting, bombing, general strikes, assassinations, or mutinies, would be a form of propaganda or mediation for escalating the struggle into a mass insurrection and what Mikhail Bakunin called “organized spontaneity" (Bakunin 1870, 183). The Delhi Bomb of 1912 followed the trends in global anarchism of assassinating heads of state from the late nineteenth to the First World War.

The idea of ghadar is comparable with how George Sorel (2008) conceptualized the general strike as myth. ${ }^{10}$ Sorel argued that class consciousness would emerge spontaneously in the moment of a direct action by producing a cleavage in society. Gramsci described the Sorelian general strike as "a creation of concrete phantasy which acts on a dispersed and shattered people to arouse and organise its collective will" (Gramsci 1971, 126). Sorel's focus was upon the spontaneous energies of the masses that could be ignited through a general strike.

The Ghadar Party's political strategy held that initiating acts of ghadar would produce a collective political consciousness and the political subject of the ghadari. The Ghadar Party believed that a ghadar would bring about, to use a Sorelian concept, a "cleavage" in society, that it would awaken subaltern consciousness, and initiate autonomous politics. While organization for the Ghadar Party involved a process of translating the spontaneous energies of the subaltern, there was also a tendency towards adventurism, an over-reliance on the under-mediated spontaneity of the subaltern classes to carry the movement forward.

While Gramsci saw it as necessary to work through the spontaneous energies of subaltern groups, he was also critical of some calls for its mobilization, as that of George Sorel on the general strike. Gramsci's critique of the Sorelian myth of the general strike was developed through his reflections about developing a national-popular collective will that were informed by the Bolshevik Revolution, which had a determining role in renewing the form and content of radical movements in Italy, India, and across the planet. It led people to re-think the role of the political party and how to develop a mass movement. It convinced Gramsci to argue that direct action of a spontaneous character could not bring about new social relations and a new state. Sorel's general strike was a negative force; it was indifferent to an organizational capacity for creative construction of a new society. Gramsci argued that Sorel considered the general strike as the highest form of political action, while leaving untheorized the capacity of mediation, the political party, or translation in producing a collective will.

10 Maia Ramnath (2011) has previously compared the Ghadar Party's idea of mutiny to the syndicalist General Strike. Ramnath argues that the Ghadar Party had been influenced by ideas of syndicalism through their Pacific Coast connections with the International Workers of the World. 
The Ghadar Party similarly went through a period of reflection in the post-war period as party members regrouped after the repression of 1915 and members were released from prison. While the Ghadar Party combined elements of spontaneity and organization, the emphasis was an undermediated notion of rebellion, where organizational form was not as important. By reflecting on the reasons for their failures and translating the experience of the Russian Revolution, ghadaris began placing more emphasis on political education for building a mass movement. The Ghadar Party was to be re-born on various political fronts, such as the Kirti Kisan Party in the late 1920s. Now the historical point of reference was 1917, not 1857; Moscow, not Delhi; the united front, not mutiny.

\section{Conclusion}

The praxis of Gramsci, Fanon, and the Ghadar Party points to how translation is not only a political practice, but is also an educational process of learning from existing struggles while also transforming them. The Ghadar Party's practice pointed to the integral role of translation in an anticolonial hegemonic project. This was a process of giving coherence to the fragmented character of subaltern desires, thoughts, memories, political struggles, and experiences of alienation. Yet, the intellectual history of anticolonialism in Punjab traced a "crooked line," with long detours into peasant knowledge (Chatterjee 1986, vii). In the Ghadar Party's re-configuration of peasant struggles against money-lenders, they arrived at a radical anticolonial perspective through borrowings from the liberal nationalist economic thought of Dadabhai Naoroji, Bengali anarchoterrorists practices like banditry, and the syndicalism of the International Workers of the World. Others have emphasized their re-configuration of Sikh thought and history (Tatla 2013). This diverse set of philosophies, tactics, and modes of organizing were translated into the radical anticolonialism that was the Ghadar Party. While many scholars have noted the eclectic character of the Ghadar Party (see for example, Ramnath 2011; Puri 1993), what has been largely sidelined in this set of literature is the essential ingredient of subaltern experience in the intellectual history of anticolonial politics. Ato Sekyi-Otu characterized such an anticolonial praxis from the writings of Fanon as the "dialectic of experience" (Sekyi-Otu 1997). For Fanon, the crooked line of anticolonial thought develops from experience, with re-adjustments and transformations in consciousness, from the knowledge of "immediacy" (Fanon quoted in Sekyi-Otu 1997, 47) or what Gramsci described as "common sense" being superseded in the process of struggle and experience. Such a framing gives a different means of understanding the open character of the Ghadar Party's anticolonial politics: it is experience that is the principal material for translation along with a diverse set of political thought that produced ghadari militancy. That the Ghadar Party learnt from peasant experience in their political education work demonstrates their organic relationship with the oppressed and exploited of Punjabi society. 


\section{References}

Bains, J. S. 1962. “The Ghadr Movement: A Golden Chapter of Indian Nationalism.” The Indian Journal of Political Science, 48-59.

Bakunin, Michail. 1870. "Letters to a Frenchman on the Present Crisis." Bakunin on Anarchism, 183-224.

Barrier, N. Gerald. 1970. The Sikhs and Their Literature: A Guide to Tracts, Books and Periodicals, 1849-1919. Delhi: Nanohar Book Service.

Bhattacharya, Neeladri. 1985. "Lenders and Debtors: Punjab Countryside, 1880-1940." Studies in History 1 (2): 305-42.

Commission, Famine. 1878. Punjab Report in Reply to the Inquiries Issued by the Famine Commission. Vol. I. Central Jail Press, Lahore.

Davis, Mike. 2001. Late Victorian Holocausts: El Nino Famines and the Making of the Third World. New York, NY: Verso.

Elam, J. Daniel. 2014. "Echoes of Ghadr: Lala Har Dayal and the Time of Anticolonialism." Comparative Studies of South Asia, Africa and the Middle East 34 (1): 9-23.

Fanon, Frantz. 2001. The Wretched of the Earth. Translated by Constance Farrington. London, United Kingdom: Penguin Books.

Foley, Griff. 1999. Learning in Social Action: A Contribution to Understanding Informal Education. London: Zed Books.

Gandre, Robert Wilbert. 1984. "Peasant Movements and Peasant Political Protest: A Case Study of the Punjab Kisan Committee, 1937-1947 (India, Pakistan).” Ph.D., New York: Columbia University.

Ghadr Party. 1919. "Catalogue of Hostile Oriental Propaganda Pamphlets (old Edition, Undated), Abstracts of Some of the Pamphlets (1914-1918), Translations of the 'Ghadr' (1915-1917), and a Catalogue of Hostile Oriental Propaganda Pamphlets (new Series, Jul 1919) Compiled by M.I.5.” Indian Office Library.

Gramsci, Antonio. 1971. Selections from the Prison Notebooks of Antonio Gramsci. Translated by 
Quintin Hoare and Geoffrey Nowell-Smith. New York, NY: International Publishers.

——_. 1992. Prison Notebooks. Edited by Joseph A Buttigieg and Antonio Callari. Vol. 1.

Green, Marcus E. 2013. "Race, Class, and Religion: Gramsci's Conception of Subalternity.” In The Political Philosophies of Antonio Gramsci and B. R. Ambedkar: Itineraries of Dalits and Subalterns, edited by Cosimo Zene. Routledge.

Isemonger, F. C, and J Slattery. 1919. An Account of the Ghadr Conspiracy, 1913-1915. Lahore: Superintendent, Government Printing.

Ives, Peter. 2004a. Gramsci's Politics of Language: Engaging the Bakhtin Circle and the Frankfurt School. University of Toronto Press.

-_- 2004b. Language and Hegemony in Gramsci. Reading Gramsci. London, United Kingdom: Pluto Press.

Josh, Sohan Singh. 1977. Hindustan Gadar Party: A Short History. Vol. I. New Delhi: People’s Pub. House.

Ker, James Campbell. 1917. Political Trouble in India, 1907-1917. Calcutta: Superintendent Government Printing, India.

Lo Piparo, Franco. 2010. “The Linguistic Roots of Gramsci's Non-Marxism.” In Gramsci, Language, and Translation, edited by Peter Ives and Rocco Lacorte, 19-28. Cultural Studies/pedagogy/activism. Lanham, United States: Lexington Books.

Morton, Adam David. 2007. Unravelling Gramsci: Hegemony and Passive Revolution in the Global Political Economy. Ann Arbor, Michigan: Plato Press.

Naoroji, Dadabhai. 1901. Poverty and Un-British Rule in India. S. Sonnenschein.

O’Dwyer, Michael. 1925. India As I Know It. London: Constable \& Co.

Patnaik, Utsa. 2011. “The Agrarian Question in the Neoliberal Era.” In The Agrarian Question in the Neoliberal Era: Primitive Accumulation and the Peasantry, 7-60. Cape Town, South Africa: Pambazuka Press.

Platts, John T. 1884. A Dictionary of Urdu, Classical Hindi, and English. London. 
Punjab Central famine relief committee. 1870. Report on the Famine in the Panjab during 186970. Punjab printing company, limited.

Punjab Government. 1915. “Secret Punjab Police Abstract of Intelligence.” 37. Lahore. National Institute of Historical and Cultural Research, Quad-i-Azam University.

Puri, Harish K. 1993. Ghadar Movement Ideology, Organisation, and Strategy. Amritsar: Guru Nanak Dev University.

Ramnath, Maia. 2011. Haj to Utopia: How the Ghadar Movement Charted Global Radicalism and Attempted to Overthrow the British Empire. Berkeley, California: University of California Press.

Santucci, Antonio A. 2010. Antonio Gramsci. Translated by Graziella Di Mauro and Salvatore Engel-Di Mauro. New York: Monthly Review Press.

Sarkar, Sumit. 1990. Modern India, 1885-1947. 2nd ed. Cambridge Commonwealth Series. Delhi, India: Macmillan.

Scott, James C. 1976. The Moral Economy of the Peasant: Rebellion and Subsistence in Southeast Asia. New Haven: Yale University Press.

Sekyi-Otu, Ato. 1996. Fanon's Dialectic of Experience. Cambridge, United States: Harvard University Press.

Sohan, Lal, Chand Fakir, and M. Bahadur Chand. 1915. "Report of the Punjab Hindu Sabha Deputation on the Dacoities Committeed against Hindus in February and March 1915 in Certain Parts of South Western Districts of the Punjab.”

Sorel, Georges. 2008. Reflections on violence. Edited by Jeremy R Jennings. Cambridge: Cambridge University Press.

Tatla, Darshan Singh. 2013. “A Sikh Manifesto? A Reading of the Ghadar Poetry.” Panjab Past and Present 44 (1): 61-81.

Thomas, Peter D. 2009. The Gramscian Moment: Philosophy, Hegemony and Marxism. Historical Materialism Book Series. Leiden, Netherlands: Brill. 
Socialist Studies / Études socialistes 13 (2) Fall 2018

Waraich, Malwinderjit Singh, and Harinder Singh. 2008. The Lahore Conspiracy Case I and II Volume I. Chandigarh, India: Unistar. 